\title{
Surgical Mesh Open Area
}

National Cancer Institute

\section{Source}

National Cancer Institute. Surgical Mesh Open Area. NCI Thesaurus. Code C112421.

A quantitative or qualitative measurement of the physical dimensions of the open spaces

in a loosely woven sheet of inorganic or biological materials, which is used to physically support organs or tissue during a surgical procedure. 